\title{
Blunt Abdominal Trauma in a Teaching Hospital, Calabar, Nigeria
}

\author{
Maurice Asuquo ${ }^{1}$, Victor Nwagbara ${ }^{1}$, Mark Umoh $^{1}$, Gabriel Ugare ${ }^{1}$, Cyril Agbor ${ }^{1}$, \\ Emmanuel Japhet ${ }^{1}$, Anthonia Ikpeme ${ }^{2}$ \\ ${ }^{1}$ Department of Surgery, University of Calabar Teaching Hospital, Calabar, Nigeria; ${ }^{2}$ Department of Radiology, University of Cala- \\ bar Teaching Hospital, Calabar, Nigeria. \\ Email: mauefas2@yahoo.com, aikay_en@yahoo.com,imezuma@yahoo.com,udeyhenugare@yahoo.com, \\ cyrilagbor07@yahoo.com,owoden_eyaaah@yahoo.com, aikpeme@yahoo.com
}

Received September $20^{\text {th }}, 2012$; revised October $29^{\text {th }}, 2012$; accepted November $19^{\text {th }}, 2012$

\begin{abstract}
Background: Road traffic injury remains a major source of blunt abdominal trauma (BAT). Road traffic injury and other forms of trauma have become a major health problem throughout the world especially in low and middle-income countries. In a previous study (2005-2007), abdominal trauma constituted 79 (4.8\%) of trauma cases; BAT, 40 (53\%) and penetrating abdominal trauma (PAT), 39 (47\%). Effective policies on road safety should be developed based on local research and not on adapted models. We present this study to highlight the possible effect of legislation on the ban of the use of motorcycles on blunt abdominal trauma. Methods: Patients that presented to the University of Calabar Teaching Hospital, Calabar with BAT from 2008-2010 were prospectively studied based on a questionnaire following the legislation prohibiting the use of motorcycles. Results: A total of 12,083 patients presented during the study period, trauma patients totaled 4942 (41\%), of this, 48 (1\%) suffered abdominal trauma: BAT 19 (40\%), penetrating abdominal trauma (PAT) 29 (60\%). The age range of the patients was from 5 to 48 years (mean 26.6 years) with a M:F = 5.3:1. Road traffic accident (RTA) 17 (90\%) [Motorvehicle 7 (37\%), motorcycles $10(53 \%)$ ] was the commonest cause of trauma. The spleen was the commonest injured organ 14 (74\%). Conclusion: Road traffic injury constitutes a public health challenge and the hallmark is prevention. Legislation prohibiting the use of motorcycles may have been responsible for the reduction in BAT.
\end{abstract}

Keywords: Blunt Abdominal Trauma; Prevention; Motorcycles

\section{Introduction}

Trauma presents a major public health challenge in Africa [1]. Road traffic injury and other forms of trauma have become a major health problem throughout the world especially in low and middle-income countries and Africa has been especially hard hit [2]. Road traffic injury remains a major source of blunt abdominal trauma (BAT) and vehicular trauma is by far the leading cause, other causes include, assault, recreational accidents or falls $[3,4]$.

Calabar, the capital of Cross River State of Nigeria with focus on tourism, is a fast developing urban town with increased vehicular traffic, which has taken its toll on trauma including BAT [5]. Calabar is reputed to be one of the first cities in Nigeria, where motorcycles were converted into commercial use and widely patronised [7].

Effective policies on road safety should be developed based on evidence of local research and not on adapted models [8]. In a previous study in this facility, (Road traffic trauma accounted for $83.6 \%$ of BAT; Motorvehicle $45.5 \%$, motorcycle $38.1 \%$ ), less use of motorcycle was recommended as most of the motorcycle accidents involved motorcycle taxis, this was in addition to other measures recommended for prevention [5].

In the year 2008, the legislation on the ban on motorcycle use in Calabar metropolis was passed and signed into law. This study, which concludes our prospective study of abdominal trauma started in 2005, presents the current pattern of BAT and the current road accident epidemiology.

\section{Patients and Methods}

Patients admitted into the University of Calabar Teaching Hospital, Calabar with blunt abdominal trauma from January 2008 to December 2010 were prospectively studied based on a questionnaire. This included biographic data, mechanism, and pattern of injuries, as well as associated injuries. Others include investigations, ini- 
tial, definitive management and outcomes.

Failure of non-operative management (NOM) was determined by clinical and laboratory evidence of ongoing haemorrhage or by development of peritonitis. Ongoing haemorrhage was defined clinically by progressive abdominal distension measured initially hourly and or tachycardia pulse $>100 / \mathrm{min}$ or hypotension systemic pressure $<90 \mathrm{mmHg}$ refractory to fluid resuscitation or progressive fall in PCV and ongoing haemorrhage confirmed by ultrasound.

On admission, patients were offered bed rest in the NOM group and post admission day three, they were allowed to start quiet activity. Patients with associated fractures were offered deep venous thrombosis prophylaxis.

Diagnosis was established by ultrasound scan on admission. The next scan was done prior to discharge to ensure absence of ongoing bleeding and four weeks post injury to monitor healing and absorption of haemoperitoneum. The patients were evaluated on an outpatients' basis weekly for 4 weeks, then monthly for two months.

The total number of patients with abdominal trauma was compared with the total emergencies and trauma injuries seen during the same period to determine their relative frequencies. Similar indices were also compared with our previous study [3] to highlight the effect of withdrawal of motorcycle taxis. Penetrating abdominal trauma (PAT) during similar periods was also compared to determine frequency of violent crimes.

\section{Results}

A total of 12,083 patients presented to the accident and emergency unit of the University of Calabar Teaching Hospital, Calabar during the study period (2008-2010). Trauma patients totalled 4942 (41\%), of this, 48 (1\%) patients suffered abdominal trauma: BAT 19 (40\%) and PAT 29 (60\%). In the previous study (2005-2007) [3], trauma accounted for 1654 (38\%) of total emergencies, abdominal trauma constituted 79 (4.8\%) of trauma cases; BAT, 40 (53\%) and PAT, 39 (47\%).

The ages of the patients ranged from 5 to 48 years (mean 26.6 years) with a M:F ratio of 5.3:1. The mechanism of injury is as shown in Table 1 comparing the current study period with our previous report (20052007). Road traffic injuries inflicted 17 (90\%) patients: Motorvehicle 7 (37\%) and motorcycle 10 (53\%). Motorcycle/pedestrian collision had decreased from 20 (48\%) in the previous study to 4 (21\%). Motorcycle related injuries were recorded in 10 (53\%) patients during the study period when compared to the previous study with 26 (62\%) patients, Table 1. Information on the 10 patients revealed that; 4 patients [2 males (cyclist), 2 females (1 passenger, 1 pedestrian)] were referrals from
Table 1. Mechanism of injury.

\begin{tabular}{|c|c|c|}
\hline Mechanism of injury & $\begin{array}{c}\text { No. (\%) } \\
(2008-2010)\end{array}$ & $\begin{array}{c}\text { No. (\%) } \\
(2005-2007)\end{array}$ \\
\hline \multicolumn{3}{|l|}{ 1) Road traffic injuries } \\
\hline $\begin{array}{l}{ }^{*} \text { Motor vehicle (MV) } \\
\text { (Driver/occupants) }\end{array}$ & $2(11)$ & $9(21)$ \\
\hline${ }^{*} \mathrm{MV} /$ pedestrian & $5(26)$ & $4(10)$ \\
\hline${ }^{*}$ Motorcycle (MC) (cyclist) & $4(21)$ & $6(14)$ \\
\hline${ }^{*}$ Motorcycle (passenger) & $2(11)$ & - \\
\hline${ }^{*}$ MC/pedestrian & $4(21)$ & $20(48)$ \\
\hline \multicolumn{3}{|l|}{ 2) Kick on the } \\
\hline Abdomen (football) & $1(5)$ & $3(7)$ \\
\hline \multirow[t]{2}{*}{ Blow on abdomen (assault) } & $1(5)$ & - \\
\hline & $19(100)$ & $42(100)$ \\
\hline "Motorcycle related injuries & $10(53)$ & $26(62)$ \\
\hline "Motorvehicle related injuries & $7(37)$ & $13(31)$ \\
\hline *Road traffic injuries & $17(90)$ & 39 (93) \\
\hline
\end{tabular}

outside Calabar, 2 male patients, [1 security agent (cyclist), 1 passenger] suffered their injuries within Calabar and these occurred during the day. Other injuries in Calabar were recorded during the night and involved 4 patients [1 male (cyclist), 1 female (pedestrian), 2 males (pedestrians)].

The commonest injured organ was the spleen, 14 (74\%), Table 2, while the liver 3 (16\%) ranked second. The patient who had non-operative management suffered splenic injury. Two other patients with splenic injury in the laparotomy group had splenorrhaphy. The 11 patients who were offered splenectomy had severe of injuries (Types IV and V), 3 patients in this group also had diseased spleen. Associated injuries inflicted 6 (32\%) patients, Table 2.

One patient with BAT enrolled successfully under the NOM group while 18 had laparotomy. The duration of admission ranged between 3 and 12 days (mean 9.5 days). The injury severity score (ISS) ranged from 4 to 22 (mean 9.9). One patient developed surgical site infection. There were fatal outcomes in $2(11 \%)$ patients (ISS 16 and 22).

The type of injury (PAT) during 2008-2010 and 20052008 did not reveal any increase in violent crimes, Table 3. In 2008-2010 violent crimes involved 19 (64\%) patients while that of 2005-2007 was 23 (84\%) [6].

\section{Discussion}

Recent finding from this study shows a decline in BAT prevalence (BAT 40\%, PAT 60\%) when compared with our previous study (BAT 53\%, PAT 47\%) [3]. This may 
Table 2. Organ/associated injury.

\begin{tabular}{cccc}
\hline Organ injury & No. (\%) & Associated injury & No. (\%) \\
\hline Spleen & $14(74)$ & Head & $2(32)$ \\
Liver & $3(16)$ & ${ }^{*} R$ femur & $1(17)$ \\
Renal & $1(5)$ & $\begin{array}{c}\text { "R humerus } \\
\text { (supracondylar) }\end{array}$ & $1(17)$ \\
Ruptured jejunum & $1(5)$ & ${ }^{*}$ L femur & $1(17)$ \\
& & Lower limb laceration & $1(17)$ \\
& $19(100)$ & & $6(100)$ \\
\hline
\end{tabular}

${ }^{\#} \mathrm{R}$ - fracture right; ${ }^{\#} \mathrm{~L}$-fracture left.

be due to a combination of factors; decline in the prevalence of BAT as a result of the ban on the use of motorcycles and/or the increase in PAT in keeping with the increased violence seen in urban areas in some major cities in the country $[9,10]$. However, the later was not the case, as the current data obtained for PAT during the same study period did not reflect that, Table 3.

The decrease in abdominal trauma (48 versus 79 ) may suggest a greater increase in the other injuries (limbs, head, and chest). However, there was a decline in the limb injuries observed during this period suggesting a trauma pattern probably due to a decline in motorcycle related injuries.

The number of traumas increased almost threefold in (2008-2010) compared to the previous period (20052007), 4942 versus 1654 . This may be due to a remarkable increase in vehicular traffic in Calabar in addition to the movement to the new accident/emergency facility that has also attracted a remarkable number of patients including referrals.

Young patients mainly males in the 3rd decade were afflicted with injuries from BAT. This is in keeping with other studies [1,3-5,12,13]. It is not surprising, as they constitute the most dynamic segment of the population with greater mobility and increased risk of accident. Of great concern is that they constitute the most productive segment of the population hence the need for their protection by institution of appropriate preventive measures.

Road traffic accidents remain the commonest cause of blunt abdominal trauma worldwide [4,13]. This is keeping with our experience; however, patients with motorcycle related injuries were commoner than motor vehicle. In keeping with local and regional accident epidemiology, in Calabar, the most common form of injury was motorcycle collision as motorcycle taxi was a common form of transportation [3,14], while in China, pedal cyclist were involved in $70 \%$ of road traffic injuries $[3,15]$.

Road traffic accident is preventable [12]. Following the ban on the use of motorcycles in Calabar metropolis, there was a significant drop in motorcycle related injuries,
Table 3. Penetrating abdominal trauma.

\begin{tabular}{ccc}
\hline Type of injury & $\begin{array}{c}\text { No. (\%) } \\
{ }^{* *}(\mathbf{2 0 0 8 - 2 0 1 0 )}\end{array}$ & $\begin{array}{c}\text { No. (\%) } \\
{ }^{++} \mathbf{( 2 0 0 5 - 2 0 0 7 )}\end{array}$ \\
\hline Stab injury & $8(28)$ & $18(46)$ \\
Gunshot & $11(38)$ & $15(38)$ \\
Fall & $3(10)$ & $1(3)$ \\
Road traffic accident & $3(10)$ & $2(5)$ \\
Machete & $4(14)$ & - \\
$\begin{array}{c}\text { Work related: cow horn } \\
\text { injury, shrapnel }\end{array}$ & - & $2(5)$ \\
$\begin{array}{c}\text { Criminal abortion } \\
\text { (impalement injury) }\end{array}$ & - & $1(3)$ \\
$\begin{array}{c}{ }^{*} \text { Violent crime } \\
\text { (Stab injury, gunshot) } \\
* *\end{array}$ & $19(66 \%)$ & $33(84 \%)$ \\
\hline
\end{tabular}

Table 1. However, out of the 10 patients with motorcycle related injuries 4 were referrals outside Calabar metropolis while 6 were within the metropolis (4 patients sustained their injuries at night when enforcement is less stringent and 2 security personnel's who are permitted to use motorcycles). Further gains are expected to be achieved with the enforcement of the ban on the use of motorcycles at night and extension of this ban or limitation to other parts of the State.

The commonest injured organ was the spleen in keeping with other studies $[1,4,13]$. The splenic salvage rate was poor because of the severity of injury to the spleen and diseased injured spleen adjudged unsuitable for conservation. The hallmark of trauma management is prevention [1]. It is hoped that a reduction in trauma based on public health education and enforcement of appropriate legislation would translate to minimisation of organ injury.

Current trend shows a decline in BAT prevalence and young mainly male patients in the 3rd decade were commonly involved in BAT. The enforcement of the legislation on the ban of the use of motorcycles may have translated to a decline in motorcycle related abdominal injuries.

\section{Conclusion}

Road traffic injury constitutes a major public health challenge and the hallmark of management is prevention based on effective policies on road safety adapted to the local road accident epidemiology.

\section{REFERENCES}

[1] G. Ruhinda, P. Kyamanywa, D. Kitya and F. Banjunirwe, 
“Abdominal Injury at Mbarara Regional Referral Hospital, Uganda,” East and West African Journal of Surgery, Vol. 13, No. 2, 2008, pp. 29-36.

[2] C. Mock, R. Quansah, R. Krishman, C. Arreola-Risa and F. Rivara, "Strenghtening the Prevention and Care of Injuries Worldwide," Lancet, Vol. 363, No. 9427, 2004, pp. 2172-2179. doi:10.1016/S0140-6736(04)16510-0

[3] M. E. Asuquo, A. U. Etiuma, O. O. Bassey, G. Ugare, O. Ngim, C. Agbor, A. Ikpeme and W. Ndifon, “A Prospective Study of Blunt Abdominal Trauma at the University of Calabar Teaching Hospital, Calabar, Nigeria,” European Journal of Trauma and Emergency Surgery, Vol. 36, No. 2, 2010, pp. 164-168. doi:10.1007/s00068-009-9104-2

[4] J. Udeani, J. Geibel, J. A. Salome, S. M. Keim, et al., "Blunt Abdominal Trauma," 2011. http://emedicine.Medscape.com/articles/1980980-overview

[5] M. Asuquo, V. Nwagbara, A. Inyang and G. Ugare, "Blunt Abdominal Trauma in Calabar," Nigerian Journal of Surgery, Vol. 16, No. 1, 2006, pp. 12-15.

[6] M. E. Asuquo, O. O. Bassey, A. U. Etiuma, G. Ugare and O. Ngim, "A Prospective Study of Penetrating Abdominal Trauma at the University of Calabar Teaching Hospital, Calabar, Southern Nigeria,” European Journal of Trauma and Emergency Surgery, Vol. 35, No. 3, 2009, pp. 277280. doi:10.1007/s00068-008-8089-6

[7] A. E. Archibong, E. E. Ikpi, I. A. Ikpeme, M. E. Asuquo, M. S. Umoh and S. G. Akpan, "Motorcycle Related Abdominal Trauma in Children in Calabar-Nigeria," Mary Slessor Journal of Medicine, Vol. 3, No. 2, 2003, pp. 4750.

[8] P. Perel, M. McGuire, K. Eapen and A. Ferraro, "Research on Preventing Road Traffic Injuries in Developing Countries Is Needed,” British Medical Journal, Vol. 328,
2004, p. 895. doi:10.1136/bmj.328.7444.895

[9] S. T. Edino, "Pattern of Abdominal Injuries in Aminu Kano Teaching Hospital, Kano, Nigeria,” Nigerian Postgraduate Medical Journal, Vol. 10, 2003, pp. 56-59.

[10] C. E. Ohanaka, P. C. Iribhogbe and R. O. Ofoegbu, "Gunshot Injuries in Benin City, Nigeria,” Nigerian Journal of Surgery, Vol. 10, 2000, pp. 1-5.

[11] S. J. Mong, J. A. Lyle and M. Black, “A Review of Gunshot Deaths in Stathclyde 1989-1998,” Medicine, Science and the Law, Vol. 41, 2001, pp. 260-265.

[12] D. Dogo, T. Yawe, A. W. Hassan and B. Tahir, "Pattern of Abdominal Trauma in North Eastern Nigeria," Nigerian Journal of Surgical Research, Vol. 2, 2000, pp. 4851.

[13] B. A. Ayoade, B. A. Salami, A. O. Tade, A. A. Musa and O. A. Olawoye, “Abdominal Injuries in Olabisi Onabanjo University Teaching Hospital Sagamu, Nigeria: Pattern and Outcome," Nigerian Journal of Orthopaedics and Trauma, Vol. 5, No. 2, 2006, pp. 45-49.

[14] M. E. Asuquo and G. Ugare, “Trauma in a Teaching Hospital Outpost: Comprehensive Health Centre, Okoyong, Cross River State, Nigeria,” European Journal of Trauma and Emergency Surgery, Vol. 36, No. 1, 2010, pp. 49-52. doi:10.1007/s00068-009-9013-4

[15] Z. Wang and J. Jiang, "An Overview of Research Advance in Road,” Traffic Injury Prevention, Vol. 4, No. 1, 2003, pp. 9-16. doi:10.1080/15389580309860

[16] M. Asuquo, M. Umoh, V. Nwagbara, G. Ugare, C. Agbor and E. Japhet, "Penetrating Abdominal Trauma: Experience in a Teaching Hospital, Calabar, Southern Nigeria," International Journal of Clinical Medicine, Vol. 3, No. 5, 2012, pp. 427-431. 